\title{
LA MEDIACIÓN COMO MECANISMO DE JUSTICIA RESTAURATIVA*
}

\author{
Alvaro E. Márquez Cárdenas Ph. D.**
}

Fecha de recibido: 8 de marzo de 2012

Fecha de aprobación: 20 de junio de 2012

Artículo resultado de investigación

\begin{abstract}
Resumen
La mediación es un mecanismo alternativo al proceso penal por medio del cual un tercero neutral, trata de permitir el intercambio de opiniones entre víctima y el imputado o acusado para que confronten sus puntos de vista y, con su ayuda, logren solucionar el conflicto originado con el delito. Se plante en el artículo los pasos para una mediación, los objetivos, la actuación de las víctimas y victimarios en el proceso, sus derechos, las consecuencias y la mediación como alternatividad procesal que puede ayudar a descongestionar la justicia penal en el país.
\end{abstract}

\section{Palabras claves}

Mediación penal, delito, víctima, justicia restaurativa, conciliación y reparación.

\section{THE MEDIATION AS A MECHANISM OF RESTORATIVE JUSTICE}

\begin{abstract}
Abstrac
The mediación is an alternative mechanism in the penal process by means of the third neutral, treating to allow the exchange of opinions between victim and the imputed or accused so that confront his points of view and with his help, attain to solve the conflict originated with the crime.
\end{abstract}

\section{Word key}

Mediation criminal offense, victim, restorative justice, reconciliation and reparation.

* El presente escrito es el resultado de la investigación terminada denominada: La mediación penal como mecanismo de justicia restaurativa. Director Dr. Alvaro Márquez, coinvestigador Dr. Rafael Velandia y el semillero de investigación en área penal, año 2010. Línea de investigación: Derecho penal. Centro de investigaciones de la Universidad Militar Nueva Granada.

** Abogado. Doctor en Derecho Por la Universidad Complutense de Madrid, España. Especialista en criminología. Instituto de criminología, U. Complutense. Master en Estudios Políticos, Universidad Javeriana, ex magistrado, Docente investigador-postgrados de la Facultad de Derecho de la Universidad Libre. Docente investigador - Centro de investigaciones de la Universidad Militar Nueva Granada, Bogotá, Colombia. Libros publicados: La víctima y los mecanismo de justicia restaurativa, La Autoría Mediata en el Derecho Penal, La Delincuencia Económica, la Coautoría en Derecho penal y la responsabilidad penal. marquez_alvaro@hotmail.com 


\section{A MEDIAÇÃO COMO UM MECANISMO DE JUSTIÇA RESTAURATIVA}

\section{RESUMO}

A mediação é um mecanismo alternativo ao processo penal por médio do qual um terceiro neutro, trata de permitir-se o intercâmbio de opiniões entre vítima e o imputado ou acusado para que confrontem seus pontos de vista e com sua ajuda, conseguam solucionar o conflito originado com o delito.

\section{Palabra-chave}

Mediação penal, delito, vítima, justiça restaurativa, conciliación e reparo.

\section{PROBLEMA}

Se busca establecer con esta regulado el instituto de la mediación como mecanismo de justicia restaurativa en el nuevo sistema procesal penal de tendencia acusatorio.

\section{RESULTADOS}

\section{LA MEDIACIÓN MATERIA PENAL ${ }^{1}$}

Según la ley 906 de 2004, normativa que introdujo por primera vez en Colombia el sistema procesal penal de tendencia acusatoria, en su artículo 523 definió esta figura como:

“... un mecanismo por medio del cual un tercero neutral, particular o servidor público designado por el Fiscal General de la Nación o su delegado, conforme con el manual que se expida para la materia, trata de permitir el intercambio de opiniones entre víctima y el imputado o acusado para que confronten sus puntos de vista $y$, con su ayuda, logren solucionar el conflicto que les enfrenta."

Plantea como forma de justicia restaurativa un mecanismo de resolución de conflictos que

1 Ver Márquez Cárdenas, Alvaro E. La víctima en el sistema acusatorio y los mecanismos de justicia restaurativa. Editorial Ibañez, Bogotá, 2011. Pag. 105 y ss. se originan con la comisión de un delito. En la doctrina encontramos varias definiciones de mediación. Así, una de ellas señala que la mediación "es un proceso por medio del cual un tercero entrenado y neutral reúne a las personas en conflicto. Las partes tienen la oportunidad para hablar sobre el conflicto y negociar su resolución, si es posible. Los mediadores no imponen acuerdos. El proceso está diseñado para dar poderes a las dos partes" 2 . Para otros la mediación en materia penal es un camino pacífico no violento ni impuesto por la administración de justicia para que los afectados con las consecuencias con un crimen puede solucionarlo entre ellos con ayuda de un tercero neutral llamado mediador. En esta misma línea, aunque con una visión más enfocada al ámbito de la empresa, se define a la mediación como "proceso por el cual un experto en mediación y negociación ayuda a las partes a negociar un acuerdo beneficioso para ambos"3

Dr. Rafael Velandia ${ }^{4}$, en la redacción del capítulo sobre la mediación en el libro la víctima y los mecanismo de justicia restaurativa, plantea que sobre el tema, debe destacarse que respecto de

2 Confróntese. http://rjp.umn.edu/img/assets/13522/ Mediating_Criminal_Conflict_England.pdf

3 Malaret, Juan. Manual de negociación y mediación. Madrid, Colex, 2003, p. 89.

4 Velandia, Rafael. La víctima y los mecanismos de justicia restaurativa. Capitulo septimo. Editorial Ibañez, Bogotá, 2011. Pag. 168 y ss. 
los orígenes de la mediación se da recuento de la práctica de la mediación en China ${ }^{5}$, hace más de dos mil años, aunque también se indica que hay documentos que indican que la mediación fue aplicada en Mesopotamia, hace cuatro mil años ${ }^{6}$.

En el ámbito colombiano, indica el profesor, tenemos que la Corte Constitucional, en la sentencia C-1195 de 2001, manifestó que "La mediación que es un procedimiento consensual, confidencial a través del cual las partes, con la ayuda de un facilitador neutral entrenado en resolución de conflictos, interviene para que las partes puedan discutir sus puntos de vista y buscar una solución conjunta al conflicto". Ahora, de manera más específica, en lo que concierne a la mediación como instrumento de resolución de conflictos originados con ocasión de la comisión de una conducta punible, el Consejo de Europa, en la Recomendación No. R(99)19 (Mediación en asuntos penales) ${ }^{7}$, definió la mediación como "un proceso mediante el cual la víctima y el ofensor $^{8}$ pueden, voluntariamente, participar activamente en la resolución de problemas que surgen del delito a través de la ayuda de un tercero imparcial o mediador. La referencia exclusiva a la víctima y al ofensor como partes no excluye otras personas participando en la mediación". Sobre la mediación en materia penal, la Corte Constitucional, en sentencia C-979 de 2005, estableció que la mediación "es un mecanismo que genera un espacio institucional para que la víctima y el ofensor (imputado o acusado) intercambien opiniones y confronten sus puntos de vista, para que a través de un mediador, que conforme a la

5 González-Capitel, Op. cit., p. 19.

6 Boqué Torremorell, María Carmen. Cultura de mediación y cambio social. Barcelona, Gedisa, 2003, p. 15.

7 Council of Europe. Recommendation No. R (99) 19 of the Committee of Ministers to member States concerning mediation in penal matters. (Citado el 15-06-06). http:// rjp.umn.edu/img/assets/18492/Council_of_Europe_\%20 $\mathrm{R}(99) 19 . p d f$

8 Entendido como el delincuente que ha agredido a la víctima. La aclaración se hace debido a que en los Derechos Penal y Procesal Penal colombiano no se utiliza la palabra ofensor. ley debe ser neutral, logren solucionar el conflicto suscitado con ocasión de la conducta punible".

En lo que a la legislación colombiana en materia procesal penal se refiere, el artículo 523 de la Ley 906 de 2004 define a la mediación como un "mecanismo por medio del cual un tercero neutral, particular o servidor público designado por el Fiscal General de la Nación o su delegado, conforme con el manual que se expida para la materia, trata de permitir el intercambio de opiniones entre víctima y el imputado o acusado para que confronten sus puntos de vista y, con su ayuda, logren solucionar el conflicto que les enfrenta".

Podemos indicar en términos generales, que la mediación se instituye como un proceso que tiene como finalidad, arreglar los conflictos con la ayuda de un mediador, que funge como tercero neutral que facilita la comunicación entre las partes, lo cual facilita que las personas en conflicto presenten su problema para ser resuelto por el diálogo o negociación, y de esa forma consigan concertar sus diferencias de una manera coordinada y cooperada, pues, la mediación no juzga. Debido a que, la meta de la misma, no es la búsqueda de la culpabilidad o inocencia de alguien, sino arreglar las diferencias de manera constructiva. El mediación se piensa más en la solución del complejo del problemas, donde la víctima es la protagonista, que en la determinación del castigo al infractor.

\subsection{Desarrollo de la mediación en el derecho penal en la comunidad internacional}

El Comité del Consejo de Europa, en la Recomendación No. 99 del 15 de Septiembre de 2004 estableció que "la mediación penal es un proceso mediante el cual la víctima e infractor adultos, voluntariamente, se reconocen capacidad para participar activamente en la resolución de un conflicto penal, gracias a la ayuda de una tercera persona imparcial: el mediador" 9 . De

\footnotetext{
9 Recomendación R (99) del 15 de Septiembre de 2004; del Comité del Consejo de Europa.
} 
tal manera que, la mediación en materia penal consiste en la gestión en la cual el mediador, actúa como facilitador de la decisión de las partes, desde su rol neutral e imparcial, es decir, tener un papel equidistante respecto a las partes. El proceso de la mediación, debe ser un proceso confidencial, es decir que, lo que se diga en la mesa de diálogo se quedará allí, pues no puede ser objeto de publicidad. Igualmente puede decirse que adquiere un carácter netamente voluntario, debido a que nadie puede ser obligado a concertar una decisión mediada sin prestar la debida conformidad. Aunque generalmente se prosigue un procedimiento reglado por la ley o la misma jurisdicción, el procedimiento en su organización es informal, por cuanto, el tiempo y las audiencias se fijan de acuerdo a las necesidades del mediador y las partes. Igualmente puede decirse que se contempla como gratuito, debido a que por lo general los agresores no poseen suficientes recursos; de tal manera que, se hace por la cooperación y autocomposición, en tanto las partes son las que auto-componen su conflicto, y necesita de su participación.

Ahora bien, el arreglo en los asuntos en que deben inmiscuirse los fiscales o jueces, se enviará al juez natural que corresponda a los fines de la homologación del mismo. Conseguir un acuerdo o arreglo en mediación en materia penal involucra que las partes fueron actores, mostrándose conforme al protagonismo de cada una, responsabilizándose de sus actos, siendo francos, sinceros y positivos. En los arreglos no se deja constancia de responsabilidad alguna, pero sí se registra el deber o compromiso que cada uno se adjudica, explicándose concretamente que tal compromiso no implica asunción de responsabilidad. El código de procedimiento penal, ley 906 de 2004, prevé que en el artículo 526 , que el mediador expedirá un informe de sus resultados y lo remitirá al fiscal o al juez, según el caso, para que lo valore y determine sus efectos en la actuación. Los resultados de la mediación serán valorados para el ejercicio de la acción penal; la selección de la coerción personal, y la individualización de la pena al momento de dictarse sentencia.
Es pertinente ahora preguntarnos ¿̇ería posible la mediación en materia penal y en materia civil en forma conjunta?, consideramos que, un solo medidor puede efectuar la mediación de manera conjunta, a fin de facilitar el arreglo o acuerdo entre las partes; pues jurídicamente no sería congruente los tiempos demandados y costos de solución frente a un único conflicto (pues una puede durar meses y la otra podría durar años); y solo restaría las respectivas homologaciones frente a las diferentes jurisdicciones. A parte de ello, si no fuese así, la justicia solo expropiaría el conflicto surgido y no tendría en cuenta el interés de la víctima; quien debe siempre ser escuchada y tener participación activa en el proceso. De tal manera que, la mediación entre el ámbito civil y el ámbito penal, deberían ser conjuntas frente a todos aquellos casos que así lo requieran, pues consideramos, que no pueden ser bifurcados o divididos los hechos, para ser tratados por dos facilitadores, o para el caso en concreto, mediadores distintos; debido a que será un desgaste procesal innecesario que atentaría contra el debido proceso, la economía y el tiempo, tanto de los que en ella intervendrían, así como para el mismo Estado.

La mediación como mecanismo de justicia restaurativa pretende la participación comunal de todos los efectos con el delito y la solución del conflicto propuesta en el proceso penal se resuelva en esta instancia las consecuencias del delito como es la indemnización y reparación para la víctima y los perjudicados, sin que los afectados tenga que acudir a un proceso civil ordinario.

\subsection{Posibles fases de las mediación penal}

La doctrina considera que la mediación como todo proceso o camino o método que pretende la solución de un conflicto complejo se surte entre los interesados, en una justicia horizontal no impuesta por el poder judicial en materia penal, mediante etapas o fases que serian las siguientes:

1. Etapa de Admisión: En ella se identifican que casos podrían ser susceptibles y apropiados 
para la mediación entre víctima y victimario. De tal manera que, la victima debe tener la adecuada disposición para participar y afrontar dicha situación para constituir un vínculo con el victimario, y por otro lado, el autor del hecho delictual debe ser un individuo dispuesto a su rehabilitación.

2. Etapa Preparatoria: Puede ser constituido por varias sesiones previas a la celebración de la mediación en cuestión, a fin de que las partes que en ella intervendrán recapaciten y mediten sobre lo que irán a exponer cuando se enfrenten el uno al otro (su objetivo está destinado a que las partes conciban el sentido de hacerse cargo y tomar responsabilidades).

3. Etapa de la Mediación: Es el llamado "careo", el cual es primordial para comprobar si es conveniente perfeccionar el intento propuesto. Dicho encuentro se lleva a cabo en un lugar neutral, donde se sientan cómodos tanto victima como victimario, y posterior a haberlos logrado entrar en confianza y legitimación suficiente, de tal manera que la mediación se celebre en reuniones conjuntas. En dicha mediación deberá haber o no acuerdo. Cuando hay Acuerdo: El contenido del compromiso puede ser variado, así puede consistir en pago en dinero a la víctima, trabajo efectuado por el infractor en su favor, trabajo para una institución de caridad inscripción del infractor en un programa de tratamiento, etc. Frente a ello, siempre tendrá que tenerse en cuenta la situación de la victima y la evaluación del victimario, su situación social y personal. $\mathrm{El}$ acuerdo se instrumenta teniendo en cuenta los intereses y requerimientos de la víctima y las posibilidades reparatorias del infractor, pues se trata de arribar a soluciones realistas y cumplibles ${ }^{10}$.

10 GONZALEZ N., La Justicia Restaurativa y el Incidente de Reparación en el Proceso Penal Acusatorio. Leyer. Bogotá D.C., 2009. pág. 64.
4. Etapa de Seguimiento: Cuando se ha llegado a un acuerdo por intermedio de la mediación, se efectúa un seguimiento posterior a la celebración de la misma, la cual tiene por objeto el control de cumplimiento, además de otros factores que permitan enderezar el cauce de lo que se propendió inicialmente. De tal manera, que si el victimario no cumple con lo establecido en el acuerdo, el operador interviniente podrá interponer la sanción penal adecuada para el caso en concreto.

Estas etapas en la mediación se estima se ajusta jurídicamente en la concepción de justicia restaurativa, debido a que es una circunstancia que se presta para que el agresor y la víctima arreglen sus relaciones interpersonales al menos como para conseguir un compromiso o acuerdo, que circunscribe la reparación. No significa ello, que lo pactado siempre satisfaga íntegramente a las partes, pues a veces, solo se alcanza una proximidad de lo estimativamente esperado. Habitualmente las partes, considerando la celeridad, lo económico del procedimiento y la gracia de sus resultados, acceden al procedimiento sin refutaciones.

Lográndose el acuerdo de solución se busca que la decisión de víctima y victimario de acudir a la mediación tenga efectos vinculantes, en consecuencia, se excluye el ejercicio de la acción civil derivada del delito y el incidente de reparación integral ${ }^{11}$.

\section{LA MEDIACIÓN PENAL COMO PROPÓSITO SOCIAL}

Una de las finalidades de la mediación en materia penal, es crear un ambiente seguro, para que el victimario y la víctima puedan acercarse, conocer la experiencia del delito de las partes mediante la ayuda de un tercero que será el mediador. En esos encuentros los afectados pueden referir sus historias, sus opiniones, proponer soluciones de conveniencia y buscar la solución mediante acuerdo dialogado entre las partes.

11 Art. 526, Ley 906 de 2004. 
Según el artículo 523 del nuevo proceso penal acusatorio, la mediación podrá referirse a la reparación, restitución o resarcimiento de los perjuicios causados; realización o abstención de determinada conducta; prestación de servicios a la comunidad; o pedimento de disculpas o perdón.

La mediación en materia penal, contempla cierto tipo de ventajas que consiste en que el acuerdo se logra en una justicia participativa y comunal donde interviene el delincuente, su familia, la víctima y los perjudicados, un miembro de la comunidad y el mediador. En algunos casos participa un consejo religioso que busca plantear el acercamiento, el perdón y el arrepentimiento como fase previa al dialogo directo entre las partes. Estos acuerdos en la práctica y la experiencia resultan más efectivo en su cumplimiento, se evita la retaliación o las vendettas. Las partes sienten que han participado en la búsqueda de justicia y para efectos generales, que interesan al Estado y la comunidad, se hizo justicia y es un factor que ayuda a la prevención del delito. La soluciones también evitan en muchas casos que los infractores se les niegue la oportunidad de seguir en libertad.

Sobre este aspecto la profesora argentina Teresa M. del Val, nos trae un caso interesante para el tema ${ }^{12}$, explica:

"... haré referencia a un caso real ocurrido en Nevada, EE.UU. se trató de dos muchachos aproximadamente de 16 años cada uno, quienes rompieron intencionalmente la vidriera de un supermercado en circunstancias en que los empleados lo estaban cerrando. A pesar de que corrieron fueron alcanzados. Dentro del modelo punitivo los jóvenes irían a un instituto de menores, en cambio se adoptó el modelo reparador -justicia restaurativa, mediación-y los menores, con el apoyo de

12 Hacemos referencia a la Mediación, como instrumento que puede llegar a prevenir la realización reiterada de conductas punibles. los padres y el consentimiento del dañado, fueron empleados en el local perjudicado a fin de que con su trabajo compensaran la compra e instalación del vidrio que habían roto. Estos jóvenes trabajaron unos meses para compensar el mal ocasionado, se responsabilizaron del hecho y restituyeron al dueño del local al estado anterior en el que se encontraba antes de su accionar.

Además recibieron tratamiento terapéutico modelo terapéutico- consiguiendo un resultado constructivo que beneficia al ofendido, al ofensor a y a la comunidad. Es de destacar que la familia también se involucró, y contó con el apoyo del ofendido y de la comunidad.

Como conclusión, puedo afirmar que seguramente estos jóvenes no querrán volver a cometer este tipo de hechos, ya que para repararlo tendrían que trabajar unos cuantos meses gratis, esto implica una enseñanza que les permitirá reflexionar acerca de sus conductas futuras. Mediar educar, enseña a reflexionar $y$, por tanto, previene el delito..."13

\subsection{Sus Privilegios y Restricciones}

González Navarro dispone como ventajas para la víctima ${ }^{14}$ :

- "La posibilidad de que el infractor rectifique en la medida de lo posible que sea a la vez valiosa para la víctima.

- La oportunidad para confrontar al autor con el verdadero impacto humano de la ofensa y a la vez para que la víctima exprese sus pensamientos y sentimientos al victimario.

13 DEL VAL, Teresa M., Mediación en Materia Penal ¿La Mediación Previene el Delito?. Editorial Universidad S.R.L. 2da. Edición Aumentada y Actualizada. Buenos Aires, 2009. pág. 67.

14 GONZALEZ NAVARRO, Antonio L., La Justicia Restaurativa y el Incidente de Reparación en el Proceso Penal Acusatorio. Leyer. Bogotá D.C., 2009. pág. 65. 
- La opción de pedir y recibir una disculpa.

- El motivo para ser visto como persona en lugar como blanco para el ataque.

- El espacio para convertir al victimario en personalmente responsable ante la víctima.

- La mayor probabilidad de que la indemnización se pague efectivamente.

- Un remedio para sentir que se ha hecho justicia.

- El medio de alcanzar un modo de conclusión que traerá paz al ánimo".

\subsection{Privilegios para el Sistema Judicial}

Primero, frente a la economía funcional del aparato judicial y al tiempo, por cuanto se disminuirá el período que requiera un proceso tramitando las ofensas penales. Y segundo, la comprensión aumentará, al igual que el sentido de pertenencia que tendrá la comunidad respecto del sistema penal; ello debido, al compromiso suscitado de victimas y participación de voluntarios.

\subsection{Privilegios para la Comunidad}

En primer lugar, disminuirá la delincuencia al aumentar la reparación de pérdidas de las víctimas. Segundo, se reduce porcentualmente el índice delictual tendiente a la reincidencia, por cuanto el infractor comprende lo que significa haber causado daño a una persona. Y por último, se le está otorgando un marco para el mantenimiento de la paz en situaciones de ofensa (por cuanto la víctima y el infractor pueden llegar a tener alguna relación en un futuro).

\subsection{Privilegios para los Victimarios}

Se le brinda la oportunidad de rehabilitación y encausarse nuevamente a la sociedad, además de resarcir el daño causado en lugar de ser castigado. Frente al resarcimiento, el infractor participa por cuanto posee la facultad de negociar.

\subsection{Restricciones en la Relación entre Víctima y Victimario}

Si bien, el mecanismo alternativo de solución de conflictos de la mediación otorga ciertos privilegios como los enunciados anteriormente, ella no es idónea para la totalidad de las víctimas y los victimarios. Pues ella, no está predestinada a solucionar de forma masiva la reincidencia de los actores. Ahora, demanda una apropiada preparación por parte de los mediadores, debido a que deben tener conocimiento de las observaciones éticas y legales involucradas en la mediación de casos penales, en virtud de las fuertes emociones que se viven por la necesidad de sancionar sujetos que quebrantan la normatividad penal.

\section{EL CONFLICTO ENTRE LA VICTIMA Y EL VICTIMARIO}

Lo fundamental de la mediación es ocuparse sustancialmente los conflictos surgidos entre ofendido y actor de la conducta delictual, del rol preponderante que cumple la víctima en la mediación, y las posibilidades que ésta última ofrece.

\subsection{El Conflicto Penal. Tipos de Conflicto.}

Para Julien Freund 15 "el conflicto penal es un enfrentamiento o choque intencional entre dos personas, también pueden ser grupos, que manifiestan los unos hacia los otros una intención hostil, generalmente hacia un derecho, en el que se trata de romper la resistencia del otro usando generalmente algún tipo de violencia (delito), lo que incluso podría llevar al aniquilamiento físico del otro". Y básicamente el ciclo del mencionado conflicto es comprendido por: (i) La escalada; lo cual quiere decir, que es el desarrollo agravado de una determinada situación, (ii) El punto muerto; distinguido por la incertidumbre y la desorientación (en este punto, es menester la

15 Citado por Entelman, Remo F.: Teoría del Conflicto... cit., p. 45. 
mediación, en tanto ella cercioraría la confianza, la seguridad y la restructuración de la relación de las partes, con la finalidad de que ella logren auto-componer el conflicto), y (iii) La desescalada; es el papel o rol del mediador como colaborador, la cual cumple su función, como facilitador y la cual debe ser desempeñada con un equilibrio equidistante entre las partes ${ }^{16}$.

Ahora, para concebir un conflicto entre dos partes, hay tres orientaciones: El cómo se observa el conflicto desde el punto de vista de las dos partes víctima y victimario y como lo plantea el mediador como tercero neutral. De tal manera que, el rol del mediador como facilitador en el ámbito penal, radicará en averiguar diferentes vías que alcancen la solución de "ganar-ganar" para las dos partes.

Por otro lado, los hechos de exaltación penal nos exhiben escenarios de una diversidad tan extensa como la vida misma, que no sería posible esquematizar de manera sinóptica, para esbozar los tipos de conflictos que surgieren, concibiendo que todos los conflictos penales incumben ser resueltos conforme a la justicia, pero el procedimiento que reciban debe ser conforme a la naturaleza de cada uno de ellos, teniendo en consideración a la víctima, al victimario y a la comunidad y por ello, la necesidad de la aplicabilidad de la justicia restaurativa.

Ahora bien, si resultaría ser imposible hacer una sistematización que condensara todas las disimilitudes de conflictos penales, es claro que la misma ley penal ínsita una distinción simple: la de los delitos de mayor cuantía y de menor cuantía ${ }^{17}$ (delitos trascendentes e intrascendentes, considerados así por algunos doctrinantes). Verbigracia, consideramos que todo acto delictivo, afecta a la comunidad. En ese entendido, en el desarrollo de algunos conflictos penales, la

16 REDORTA, Josep. Entender el Conflicto, Paidós, Barcelona, 2007. Pág. 132

17 Delitos que requieren querella de parte de delitos de acción propia y los delitos investigables de oficio que tienen un pena considerablemente mayor. mediación no siempre podría ser admisible para algunos casos, siendo así ineludible la respuesta habitual al accionar delictivo. Sin embargo, como quiera que el conflicto ha sido apreciado siempre como un problema, para la mediación es una ocasión para que las partes puedan comunicarse a fin de hallar en forma colaborativa (si es dable) un arreglo que satisfaga los intereses de ambas partes dentro de un marco legal.

Por su parte, Johan Galtung ${ }^{18}$ clasifica el conflicto penal, así:

- Microconflicto, se presenta entre personas, es decir, en materia penal el delito que unas personas o varias cometen contra otra u otras;

- Mesoconflicto, cuando el conflicto surge dentro del Estado o nación;

- Macroconflictos, serían los conflictos delictivos que pueden surgir entre Estados y/o naciones, $y$

- el Megaconflicto, estaría conformado por los hechos delictivos que se producirían entre civilizaciones o regiones del planeta.

\subsection{Mediación desde el Punto de Vista de la Víctima.}

La víctima de la que se ocupara en el derecho penal y la victimología con la cual surgió la justicia restaurativa, es la víctima del delito común. El victimario es aquel que ocasiona el sufrimiento. Pueden haber víctimas, pero no por la comisión de un hecho considerado punible, sino por otro tipo de hechos. Se puede ser víctima sin injerencia de la conducta humana, como por hecho de la naturaleza o se puede ser víctima por actos llevados a cabo por el propio ofendido, por su actuar imprudente o porque pretende autolesionarse o suicidarse por ejemplo.

En el Séptimo Congreso de las Naciones Unidas sobre prevención del Delito y Tratamiento del Delincuente, en la Declaración sobre Justicia y Asistencia para las Víctimas, se establece que:

18 ROZEMBLUM DE HOROWITZ, Sara. Mediación. Graó, Barcelona, 2007, pág. 113. 
[...] "victima es la persona que ha sufrido una lesión o daño físico o mental, una pérdida o daño material, o cualquier otro perjuicio social como resultado de una acción que:

a) Esté en violación con las leyes penales nacionales;

b) es un crimen catalogado bajo la ley internacional, o

c) constituye una violación a las normas de los derechos humanos internacionalmente reconocidos que protegen la vida, la libertad y la seguridad nacional, o

d) I) constituye un "abuso de poder" ejercido por personas que, en razón de su posición política, económica o social, ya sean oficiales políticos, agentes o empleados del Estado o entidades comerciales, estén "fuera del alcance de la ley, o

II) que aunque no esté realmente proscrito por la leyes nacionales o internacionales cause daños físicos o psicológicos o económicos comparables a los causados por los abusos de poder, constituyendo de esta forma un delito dentro de la ley internacional o una violación a las normas internacionalmente reconocidas de los derechos humanos y cree serias necesidades en sus víctimas similares a las causadas por violación de esas normas.

El término "víctima" incluye a toda persona que ha sufrido una perdida, daño o lesión, ya sea como individuo o como integrante de un grupo o colectividad.

El término "persona" se referirá a personas legales, organizaciones, asociaciones, comunidades, el Estado o la Sociedad en un todo" $[\ldots]^{19}$

197 mo. Congreso de las ONU, sobre Prevención del Delito y Tratamiento del Delincuente. Anexo 1: Declaración sobre Justicia y Asistencia para las Víctima, celebrado en Italia del 26 de agosto al 06 de septiembre de 1985.
Según esta recomendación de Naciones Unidas, los derechos de las víctimas están basados en el derecho a la vida, la libertad y la seguridad personal; y si el daño no les es resarcido por parte del victimario por sus escasos recursos, operará entonces la figura de la "compensación", donde el Estado tendrá que asistir a las víctimas mediante programas que deberán ser creados a tales efectos; pues las víctimas, deberán disponer de la asistencia material, psicológica y social necesaria, incluyendo ayuda médica y psiquiátrica, ayuda financiera y servicios legales.

Finalmente, la citada Declaración, reconoce tres clase de víctimas: 1 . La que consta en la definición mencionada en la misma; 2. Los familiares o personas a cargo, y; 3 . Las víctimas del abuso de poder.

Doctrinalmente también encontramos definiciones como la de Hilda Marchiori, quien manifiesta que víctima es la persona "que padece la violencia por causas del comportamiento del individuo que trasgrede las leyes de su sociedad y cultura. De este modo, la víctima está íntimamente vinculada con el concepto de consecuencias del delito, que se refiere a los hechos o acontecimientos que resultan de la conducta antisocial, sobre todo el daño, la extensión de éste y el peligro causado individual y socialmente" 20 . De tal manera que, la consternación o sufrimiento de la víctima es ocasionada por el acto violento al que fue sometido por otro individuo.

Hans Von Hentig, en su libro el Crimen y sus víctimas, explica el proceso de sufrimiento por la que pasan quienes son objeto de un delito. Sufrimiento que nos recuerda que los perjudicados no deben ser ignorados o marginados por el proceso penal donde estos tienen mucho que decir y ser parte en la solución del conflicto en una forma de justicia participativa como es la restaurativa y por antonomasia la mediación penal. Esta forma de victimización que menciona el autor son la siguientes y que deben repararse:

20 MARCHIORI, Hilda. La víctima del delito, Lerner, Córdoba, 1990. 
1. Victimización Primaria: Es la que padece un individuo en particular.

2. Victimización Secundaria: Es la dirigida contra grupos específicos (una parte especifica de la población).

3. Victimización Terciaria: Es la que padece la comunidad en general (es la llamada victimización supranacional).

Algunos autores mencionan otra forma de victimización que sufre el delincuente cuando es sometido y reducida su libertar en las cárceles en unas condiciones infrahumanas.

Entendidas así las cosas, sin víctima no puede haber delito. Winfried Hassemer menciona que "la víctima es un partícipe necesario en las constelaciones de delitos más clásicas: hurto, robo, estafa, lesiones, homicidios o injurias. Quien no encuentra un objeto de ataque válido como víctima no podrá ser autor de un delito". La víctima, es el sujeto pasivo del delito, el cual es el titular del bien jurídicamente tutelado, que se encuentra ofendido o amenazado, $y$ que puede resultar no solamente en cabeza del individuo persona natural, sino también de entidades colectivas como el Estado, asociaciones, $e$ inclusive comunidades, tales como la familia y la sociedad. Así las cosas, es menester afirmar que, la mediación es prestante para cualquiera de los ofendidos mencionados.

\subsection{Posibilidades que Ofrece la Mediación en la solución del conflicto.}

Normalmente la condición de víctima en el proceso penal, está representada en por actos jurisdiccionales puramente probatorios; pues, en innumerables ocasiones se revictimiza por el mismo procedimiento; al no ser escuchada acorde a los intereses que ella tiene, debiendo esperar mucho tiempo para ser testigo del cargo que se le imputa a su agresor, y donde el Estado ha concebido su conflicto sin tenerla en cuenta. Así, "el Estado privilegia el mal llamado bien jurídico protegido, cuando en realidad debería denominarse el bien jurídico perpetrado a la víctima-ofendido, pues la tipificación coincide con el hecho cometido que damnifica a una victima-ofendido. No hay protección a ningún bien, ya que parece la sanciónpena cuando el hecho se cometió, precisamente por no existir adecuada prevención"21.

Entendamos entonces que, la conducta punible no ha sido ocasionada en contra del Estado, sino que ha vulnerado la integridad física y moral de un individuo en particular. De tal manera, que entraría la medición, como un camino diferente a seguir, en favor de la relación agresor-víctima (aspecto humano), en aquellos delitos considerados ser objeto de mediación. En tanto que, en muchas ocasiones en delitos donde se impone una pena privativa de libertad, origina un sufrimiento más profundo que el causado por la misma conducta punible, lo que resignaría tanto al agresor como a la víctima, y en general, a la misma sociedad. Es decir, se agrava la situación de los sujetos involucrados en el hecho punible.

En efecto, por un lado, el agresor se hace acreedor de una retribución por su conducta que lo estigmatizará, en la medida que le corresponderá soportar una pena, y por el otro, la víctima, que por su parte, tampoco queda conforme tras el proceso, porque no asiente que se le hayan resarcido el daño ocasionado por la conducta desplegada por su victimario; quedando insatisfecha y peor aún, revictimatizadola con ocasión a lo dispendioso del proceso penal; al no ser escuchada en debida forma y haciéndola sentir nuevamente lo sufrido).

Es por ello, que consideramos benéfico, restituirle el protagonismo que siempre ha debido tener el mencionado ofendido que, por intermedio de la "mediación", que se vislumbra como una vía adecuada para otorgarle la posición que necesita, se le proporcione la ocasión, para que el daño le sea reparado, restituyéndolo total o parcialmente. En la de mediación penal, el ofendido y su agresor, podrán auto-componer el conflicto, y llegar a un acuerdo común entre las partes, para la reparación

21 Del VAL, Teresa M. Mediación en materia penal... cit. pág. 55. 
del respectivo hecho. Pues, el perdón y el diálogo son las formas más adecuadas y cómodas; para obtener la satisfacción de sus intereses. En tanto, el arrepentimiento y el compromiso de enmienda, y el perdón, ocasionan la voluntad de retornar y mantener una sana convivencia, lo cual tendrá mucho más valor que una providencia judicial.

Así las cosas, la "mediación" es un mecanismo no adversarial, donde un tercero neutral, llamado mediador, lleva un asunto de negociación asistida, con la finalidad de que los participantes, logren un arreglo (es otro camino, totalmente diferente al tradicional, para gestionar y resolver conflictos penales entre víctimas y agresores). La cual es válida en conflictos de carácter punitivo, donde las partes buscan directamente una respuesta que satisfaga sus intereses más íntimos; pues, el objetivo principal del mecanismo en el ámbito penal, es el restablecimiento de las relaciones interpersonales mediante una comunicación.

\section{MEDIACIÓN COMO POLÍTICA CRIMINAL EN EL PROCESO PENAL COLOMBIANO}

En la actualidad el aparato jurisdiccional y su cimiento legal se hallan desfasados de las necesidades de resolución que tienen las controversias interpersonales surgidas en la sociedad. Ello, impide dar una respuesta específica a las necesidades sociales, con la resultante deslegitimización para la institución judicial en materia penal ${ }^{22}$.

Tradicionalmente, la jurisdicción ha concebido los litigios con el formalismo de la ritualidad que demanda la normatividad penal; que aporta soluciones específicas respecto a los conflictos que se presentan. Lo cual élitiza la respuesta procesal al conflicto en detrimento de cada litigio en concreto; por tanto, se requieren posibilidades que solucionen tal situación. Y como

22 El proceso penal y su sanción es un problema que ocupa al Estado en una justicia retributiva que nos se ocupa de las necesidades de la víctima a quien solo considera como objeto de prueba con sus testimonio de cargo. quiera que, no todas las conductas le interesan al derecho penal, y peor aún, rara vez soluciona el conflicto de la víctima ${ }^{23}$; genera en la ciudadanía, insatisfacción respecto de la tramitación judicial de esas controversias, debido a que ellas se manejan dentro de variables de poca posibilidad de éxito; pues tales conflictos, son menoscabados por la "maquinaria judicial" que rechaza metódicamente los asuntos que no se hallen catalogados dentro del trámite, para lo cual, también deben encontrarse entrenados los operadores judiciales; por ello, y por muchas otras falencias, los resultados que se ven a diario, tales como: archivos, desistimientos, prescripciones, demoras en el trámite, etc. Afecta a la victima que ve que su caso no ha tenido justicia. De esta manera, la víctima se ve revictimatizada, por la defraudación que le ocasiona el sistema judicial. Es necesario darle el protagonismo a la víctima en proceso penal como lo plantean los nuevos criterios de la victimología.

Como planteamos inicialmente, la mediación es un mecanismo de justicia restaurativa que tiene el alcance de hacer efectiva la reparación ${ }^{24}$, en el entendido que crea un espacio corporativo en el que la víctima y el agresor se comuniquen y cotejen sus puntos de vista, para que por intermedio de un facilitador neutral (mediador), logren solucionar el conflicto originado por la comisión de un acto delictivo. Por tanto, la mediación debe enfocarse en objetivos restauradores, tales como; la reparación, la restitución, el resarcimiento de los perjuicios causados, la realización o abstención de determinada conducta, la prestación de servicios a la comunidad, o el ofrecimiento de disculpas o perdón. Se trataentonces la mediación, de un mecanismo al que pueden concurrir la víctima y/o el agresor (sea imputado o acusado), desde la formulación de imputación y hasta antes del juicio oral; ante lo cual, se le solicitará al fiscal de la causa, el juez con funciones de control de garantías, o el juez de conocimiento ${ }^{25}$.

23 Debido a que el mismo sistema penal, no puede reponer las cosas al estado anterior al hecho.

24 Sentencia C-979 de 2005.

25 Dependiendo en la etapa procesal penal en que se formalice la respectiva solicitud. 
En Colombia, la mediación opera bajo dos aspectos con consecuencias diferentes; y con el objeto de insertar la flexibilización de la respuesta punitiva en el Estado Social y Democrático de Derecho, su alcance trasciende el ámbito de los delitos querellables ${ }^{26}$, para extenderse a los delitos de persecución oficiosa, de acuerdo al precepto legal demandado por la normatividad. Es decir, en Colombia, la mediación como mecanismo de justicia restaurativa, es posible aplicarla para delitos graves como por ejemplo, el homicidio, secuestro, extorsión, lesiones graves, etc., y no para hechos de poca importancia para la cual se acudiría a la conciliación que también es regulado legalmente como mecanismo de justicia restaurativa.

El artículo 524 del nuevo procedimiento penal de tendencia acusatorio expresa que son requisitos para acudir a la mediación penal, cuando se den los siguientes supuestos: (i) Que se trate de delitos perseguibles de oficio cuyo mínimo de pena no exceda de cinco años. Si se excede de este número de años se puede seguir con la mediación pero cambia la competencia del fiscal para el tramite; (ii) que el bien jurídico protegido no sobrepase la órbita personal del perjudicado, caso de los delitos contra la administración de justicia; (iii) y que la víctima, imputado o acusado acepten expresa y voluntariamente someter su caso a una solución de justicia restaurativa ${ }^{27}$.

Ahora, los efectos jurídicos que la norma dispensa a la aplicación de la mediación en estos delitos de baja punibilidad, se enfoca en dos aspectos; el primero, en lo concerniente a la responsabilidad civil emanada de la comisión del hecho punible, donde el acuerdo alcanza efectos vinculantes, lo que significa que prescinde los otros dispositivos que apuntan a este mismo objetivo, como son la acción civil de manera independiente, y el incidente de reparación integral ${ }^{28}$.

\footnotetext{
26 Los cuales son propios del Mecanismo Alternativo de Solución de Conflictos, llamado Conciliación.

27 Artículo 524, inc. $1^{\circ}$ de la Ley 906 de 2004

28 Artículo 526, inc. $1^{\circ}$ de la Ley 906 de 2004
}

Respecto a la responsabilidad penal en ocasión a la comisión derivada del delito, la acción penal podría extinguirse por aplicación del principio de oportunidad, acorde a la causal octava del artículo 324 de la Ley 906 de 2004 que preceptúa "cuando proceda la suspensión del procedimiento a prueba en el marco de la justicia restaurativa, y como consecuencia de éste se cumplan con las condiciones impuestas". Dicha suspensión radica en la prerrogativa del agresor, en requerir la suspensión del procedimiento, por un período de prueba el cual no podrá ser superior a tres años, sometida al compromiso de un plan de reparación integral del daño y al acatamiento de las condiciones estipuladas en el artículo $326^{29}$ de la norma procesal penal que establece que el procesado beneficiado con la suspensión del proceso a prueba dentro del marco de los preceptuado en la filosofía de la justicia restaurativa debe:

a) Residir en un lugar determinado e informar al Fiscal del conocimiento cualquier cambio del mismo.

b) Participar en programas especiales de tratamiento con el fin de superar problemas de dependencia a drogas o bebidas alcohólicas.

c) Prestar servicios a favor de instituciones que se dediquen al trabajo social a favor de la comunidad.

d) Someterse a un tratamiento médico o psicológico.

e) No poseer o portar armas de fuego.

f) No conducir vehículos automotores, naves o aeronaves.

g) La reparación integral a las víctimas, de conformidad con los mecanismos establecidos en la ley.

h) La realización de actividades a favor de la recuperación de las víctimas.

i) La colaboración activa y efectiva en el tratamiento psicológico para la recuperación

29 En el parágrafo de este articulo se indica que durante el periodo de prueba el imputado o acusado hasta antes de la audiencia deberá someterse a la vigilancia que el fiscal determine sin menoscabo de su dignidad. Vencido el periodo de prueba y verificado el cumplimiento de las condiciones, el fiscal solicitará el archivo definitivo de la actuación previo control por parte del juez de garantía. 
de las víctimas, siempre y cuando medie su consentimiento.

j) La manifestación pública de arrepentimiento por el hecho que se le imputa.

k) La obligación de observar buena conducta individual, familiar y social.

1) La dejación efectiva de las armas y la manifestación expresa de no participar en actos delictuales.

m) La cooperación activa y efectiva para evitar la continuidad en la ejecución del delito, la comisión de otros delitos y la desarticulación de bandas criminales, redes de narcotráfico, grupos al margen de la ley.

Así, agotado el período de prueba y comprobado el cumplimiento de las codificaciones impuestas durante el periodo de prueba, entonces el fiscal ordenará el archivo de la diligencia penal, conforme a la causal octava del citado artículo 324; que posteriormente será sometida control judicial por parte del juez con funciones de control de garantías.

El segundo aspecto de aplicación de la mediación ${ }^{30}$, es el que gira en torno a delitos perseguibles de oficio con pena superior a cinco (5) años; donde el mecanismo de la mediación resulta aplicable, pero donde sus efectos son esencialmente diferentes, específicamente con respecto a la acción penal; porque si bien, sobre estos punibles, la decisión de la víctima y el agresor al acudir a la mediación es lograr efectos vinculantes con respecto a la obtención del resultado restaurativo, exceptuando la eventualidad de acudir a la acción civil derivada del hecho punible de manera independiente, y al incidente de reparación integral; en lo que concierne a la acción penal los efectos se limitan ampliamente, debido a que, la mediación otorgará únicamente al imputado, acusado o sentenciado, beneficios procesales durante el proceso; que podrá ser, al momento de la imposición de la pena para lo que respecta a su dosificación, o en la fase de ejecución de la sanción. De esta manera la aplicación de la mediación penal en delitos graves resulta de beneficio tanto a la víctima como al procesado, pues en estos, delitos investigables

30 Art. 524, inc. $2^{\circ}$, de la Ley 906 de 2004 de oficio la norma penal generalmente predica como medida de aseguramiento la privación de la libertad, que los mecanismos de justicia restaurativa, el juez escuchando la víctima puede reducir la medida carcelaria o a una condena de ejecución condicional o una prisión domiciliaria.

\section{EL MEDIADOR: ¿PARTICULAR O SERVIDOR PÚBLICO ${ }^{31}$ ?}

El artículo 523 de la Ley 906 de 2004 instituye que la "Mediación es un mecanismo por medio del cual un tercero neutral, particular o servidor público designado por el Fiscal General de la Nación o su delegado, conforme con el manual que se expida para la materia, trata de permitir el intercambio de opiniones entre víctima y el imputado o acusado para que confronten sus puntos de vista y, con su ayuda, logren solucionar el conflicto que les enfrenta". De esta manera, podemos apreciar que la redacción del artículo 523 es de una claridad absoluta y debe estimarse, por ende, que el cargo de mediador puede ser ejercido tanto como particulares como por servidores públicos. Por otra parte, debemos destacar que en el Manual de Procedimientos de Fiscalía en el Sistema Penal Acusatorio Colombiano se señala que las listas de elegibles para el cargo de mediador se elaborarán cada dos años y que estarán "integradas por servidores públicos, aún de la Fiscalía General de la Nación excepto fiscales. También por personas particulares pertenecientes a centros de conciliación, consultorios jurídicos, practicantes universitarios, colegios de abogados, organizaciones no gubernamentales, entre otros".

Consideramos pertinente indicar en este momento que la parte del manual que hace referencia a los particulares debe ser interpretada en el sentido de que el particular no necesariamente debe pertenecer a una de las organizaciones que se mencionan (Centros de conciliación, etc.). En efecto, si se

31 En el libro la Victima y los mecanismos de justicia restaurativa, el Dr. Rafael Velandia coinvestigadores del trabajo y autor del capítulo quinto de esa investigación comenta sobre estos temas que traemos a colación. 
considera que, de acuerdoal manual, los particulares solo pueden ser nombrados como mediadores si pertenecen a alguna de las organizaciones citadas, o alguna otra similar, que estamos en presencia de un exceso en la potestad concedida por el artículo 527 al Fiscal General de la Nación, pues es evidente que el artículo 523 no exige al particular ninguna vinculación a ninguna organización para poder ejercer como mediador, por lo que mal podría hacerlo el manual, cuya labor consiste en fijar las directrices de funcionamiento de la mediación y no puede modificar a la ley, mucho menos cuando es tan clara en su redacción como el artículo 523.

En conclusión, tanto particulares, como servidores públicos pueden fungir como mediadores en procesos penales, sin más limitaciones que las de las causales de impedimento del artículo 56 de la Ley 906 de $2004^{32}$. Pero se aclara que todos los particulares o funcionarios públicos, sino aquellos que tenga una formación especial en materia penal que permite resolver un conflicto originado con el delito, por lo tanto, deberán se abogados y dedicados al derecho criminal con conocimiento en nuevo sistema oral acusatorio, pues la solución al caso, el fiscal debe recogerla y presentarla para su legalización al juez de garantía, primero para aprobar la iniciativa y segundo para posteriormente si es del caso archivar a causa penal. Los funcionarios públicos que en nuestra opinión, podrían realizar esta actividad de mediadores serian los Agentes del Ministerio Público que actúan en los diferentes juzgados penales y no otros empleados públicos por su especial capacitación en el tema penal.

De acuerdo a lo establecido Ley 906 de 2004, la mediación podrá solicitarse por la víctima o por el imputado o acusado ante el fiscal, juez de control de garantías o juez de conocimiento, según el

32 En este caso aunque la Ley 906 de 2004 no establece nada al respecto, consideramos que el manual no excede la reserva legal, en la medida que el sistema de impedimentos e inhabilidades es puede ser considerado como una directriz para el funcionamiento de la justicia restaurativa, además, este mandato no contradice a la ley de ninguna manera. caso, para que el Fiscal General de la Nación, o su delegado para esos efectos, proceda a designar el mediador. En los casos de menores, inimputables y víctimas incapaces, sus representantes legales deberán participar en la mediación.

\section{ETAPA PROCESAL EN LA QUE PROCEDE LA MEDIACIÓN}

De acuerdo al artículo 524 de la Ley 906 de 2004, la mediación puede llevarse a cabo desde la audiencia de formulación de la imputación y hasta antes de que comience el juicio oral, es decir, hasta antes de la instalación de la audiencia que da comienzo a aquel. Es decir, en términos generales, la mediación se puede llevar a cabo tanto en la etapa de investigación, como en la de juicio, aunque con unos límites específicos: en la etapa de investigación la oportunidad para llevar a cabo la mediación partiría desde el momento en que se formule la imputación y hasta antes de que el fiscal del caso presente el escrito de acusación ante el juez competente; a su vez, la mediación en la etapa del juicio se podría llevar a cabo desde el momento en el que se presente el escrito de acusación, que es cuando comienza la etapa del juicio, y hasta antes de que se dé comienzo al juicio oral.

En definitiva, la mediación puede darse en las dos etapas principales del proceso, investigación y juicio. Es más, se puede de a acudir a los mecanismos de justicia restaurativa: conciliación y mediación penal, cuando el proceso ha sido condenado, cuando se esté tramitando el incidente de reparación integral. Y diría aun más, cuando la persona está cumpliendo efectivamente la pena privativa de la libertad en la cárcel. Situación donde la opinión de la víctima es fundamental para concede al prisionero la oportunidad de la libertad, aun cuando no haya cumplido las dos tercera partes de la penal para como requisito de ser beneficiado con un subrogado penal. Lo anterior es posible porque la justicia restaurativa como quedo en el nuevo sistema procesal penal de tendencia acusatorio, es una filosofía, es otra forma de ver y aplicar la justicia sin estar sujeto a lo rigurosos procedimientos normativos de un proceso penal. 


\section{DELITOS PARA LOS QUE PROCEDE LA MEDIACIÓN PENAL}

En términos generales, que la mediación procede para todos los delitos. Lo que ocurre es que la ley da alcances diferentes a la mediación de acuerdo al delito, según se explicará a continuación.

- Delitos querellables: en principio, en este tipo de delitos la conciliación es el mecanismo de justicia restaurativa al que las partes deben acudir. En efecto, el artículo 522 de la Ley 906 de 2004 establece que la conciliación es requisito de procedibilidad para el ejercicio de la acción penal y que debe llevarse a cabo ante el fiscal que corresponda, o en un centro de conciliación o ante un conciliador reconocido como tal. A su vez, el artículo 524 ibídem instituye que la mediación procede para los delitos perseguibles de oficio cuyo mínimo de pena no exceda de cinco años de prisión, aunque en el inciso segundo del mismo artículo abre la puerta a la aplicación de la mediación en delitos perseguibles de oficio cuyo mínimo de pena sí exceda de cinco años de prisión, sólo que las consecuencias son diferentes. De acuerdo a lo expuesto podría pensarse que la mediación estaría excluida como mecanismo de justicia restaurativa en el caso de delitos querellables. Sin embargo, el inciso segundo del artículo 522 ibídem abre campo a la posibilidad de la práctica de la mediación en delitos querellables, pues determina que si la conciliación fracasa, bien sea por falta de acuerdo o por falta de asistencia del querellado, el fiscal del caso deberá proseguir con el ejercicio de la acción penal, sin perjuicio "de que las partes acudan al mecanismo de la mediación". En estos caso cuando fracasa la conciliación se recomienda es acudir otra vez a este mecanismo por resultar más económico, mas rápido y fácil la mediación es un proceso mas dispendioso, demorado y costos prevista para delitos de mayor gravedad.

- Delitos perseguibles de oficio cuyo mínimo de pena no exceda de cinco años de prisión: en este caso procede la mediación, siempre y cuando el bien jurídico protegido no sobrepase la órbita personal del perjudicado, y víctima, imputado o acusado acepten expresa y voluntariamente someter su caso a una solución de justicia restaurativa. En Colombia las penas aumentaron considerablemente con fin que el fiscal tuviera elementos para poder negociar. Con esto poco delitos tienen pena mínima de cinco años, por ello debemos acudir al inciso del artículo 524 del código de procedimiento penal que establece que en los delitos con pena superior a cinco años la mediación será considerada para otorgar algunos beneficios durante el trámite de la actuación, o relacionados con la dosificación de la pena, o el purgamiento de la sanción. Es decir, la mediación penal en Colombia se aplica en general para todos los delitos investigables de oficio.

- Delitos perseguibles de oficio cuyo mínimo de pena sí exceda de cinco años de prisión, como indicamos arriba, siempre y cuando el bien jurídico protegido no sobrepase la órbita personal del perjudicado, y víctima, imputado o acusado acepten expresa y voluntariamente someter su caso a una solución de justicia restaurativa: en este tipo de delitos también procede la mediación.

Lo que debe quedar claro es que en que el caso de los delitos querellables y de los delitos perseguibles de oficio cuyo mínimo de pena no exceda de cinco años de prisión, la mediación puede llevar a que el fiscal al que le ha correspondido conocer el caso decida no ejercer la acción penal, como ya mencionamos, posibilidad que no existe en el caso de los delitos perseguibles de oficio cuyo mínimo de pena sí exceda de cinco años de prisión. En los tres casos de esta división legal, la mediación puede tener efectos en cuanto a beneficios durante el trámite del proceso, dosificación punitiva y purgamiento de la sanción impuesta. Así mismo, en las tres clases de delitos, la mediación exitosa excluye la posibilidad del ejercicio de acción civil por responsabilidad generada del delito, al igual que, por lógica, impide el ejercicio del incidente de reparación integral.

Debe señalarse, sin embargo, que lo más lógico es que en la realidad la mediación en delitos 
querellables tenga poco uso, pues es más expedito recurrir al acuerdo privado entre querellante y querellado, que tendría como consecuencia la presentación de un desistimiento de la querella, que acudir al mecanismo de la mediación. De todas maneras, las partes ${ }^{33}$, una vez fracasada la conciliación de que trata el artículo 522 de la Ley 906 de 2004, estarían en libertad de recurrir a la mediación pero teniendo en cuenta que esta tendría que tener lugar antes de que venza el término establecido en el artículo 175 ibídem, si se quiere que la mediación tenga efectos respeto del ejercicio de la acción penal, es decir, para que el fiscal pueda aplicar el principio de oportunidad. De todas maneras, consideramos que en el caso de que haya pasado la oportunidad del artículo 175 citado y el fiscal haya presentado escrito de acusación, las partes podrían acudir a la mediación, solo que la mediación no tendría consecuencias sobre el ejercicio de la acción penal, sino solo para otorgar algunos beneficios durante el trámite de la actuación, para la dosificación de la pena o beneficios para el purgamiento de la sanción, según corresponda. Sin embargo, cuando el fiscal haya presentado el escrito de acusación, y si las partes desean terminar con el proceso penal, les quedaría la opción del desistimiento de la querella: así, podría darse el caso de un acuerdo privado entre ofensor $y$ víctima ${ }^{34}$, que sea satisfactorio para esta, lo que podría llevar a que se presente el desistimiento, que tendría que presentarse antes de que finalice la audiencia preparatoria, y que tendría como efecto la terminación del proceso.

Finalmente, a continuación se presenta una lista de los que se considera que son delitos perseguibles de oficio cuyo mínimo de pena no excede de cinco años de prisión, siempre y cuando el bien jurídico protegido no sobrepase la órbita personal del perjudicado, y víctima, imputado o acusado acepten expresa y voluntariamente someter su caso a una solución de justicia restaurativa. Es decir, se trata de aquellos delitos en los que "Los resultados de la mediación serán valorados para el ejercicio de

33 Entendidos como víctima y ofensor.

34 Siempre y cuando sea el sujeto pasivo del delito, condición que no siempre la víctima satisface. la acción penal; la selección de la coerción personal, y la individualización de la pena al momento de dictarse sentencia". Como se puede apreciar, destacamos el hecho de que se trata de delitos cuya investigación se adelanta de oficio, motivo por el cual quedan excluidos de esta lista los delitos querellables, a pesar de que ellos puedan ser objeto de mediación, luego de que se haya intentado la conciliación preprocesal. Estos delitos son:

Articulo 112. Incapacidad para trabajar o enfermedad ${ }^{35}$, articulo 113. Deformidad ${ }^{36}$, articulo 114. Perturbación funcional ${ }^{37}$, artículo 115. Perturbación psíquica ${ }^{38}$, artículo 131 omisión de socorro $^{39}$, articulo 182. Constreñimiento ilegal, articulo 184. Constreñimiento para delinquir, articulo 186. Fraudulenta internación en asilo, clínica o establecimiento similar, articulo 187. Inseminación artificial o transferencia de ovulo fecundado no consentidas articulo 189 . Violación de habitación ajena, articulo 191. Violación en lugar de trabajo, articulo 192. Violación ilícita de comunicaciones, articulo 194. Divulgación y empleo de documentos reservados, articulo 195. Acceso abusivo a un sistema informático, artículo 201 violación a la libertad religiosa, articulo 206. acto sexual violento, articulo 207. acceso carnal o acto sexual en persona puesta en incapacidad de resistir ${ }^{40}$, articulo 213. Inducción a la prostitución, artículo 220 injuria ${ }^{41}$,

35 Siempre y cuando sea lesiones personales que produjeren incapacidad para trabajar o enfermedad que exceda de sesenta (60) días y la imputación sea a título de dolo. También si la incapacidad es inferior a 60 días y el sujeto pasivo sea un menor de edad, pues en este caso no es necesaria la querella. Empero, los menores deberán estar acompañados de sus representantes legales, que deben participar en la mediación (ARTíCULO 525, inciso $2^{\circ}$, de la Ley 906 de 2004).

36 Siempre y cuando la imputación sea a título de dolo o si el sujeto pasivo es un menor de edad.

37 Ibíd.

38 Ibíd.

39 Siempre y cuando el sujeto pasivo sea un menor de edad.

40 Sólo si se trata de acto sexual diferente al acceso carnal.

41 Siempre y cuando el sujeto pasivo sea un menor de edad. 
artículo 221 calumnia $^{42}$, artículo 222 injuria y calumnia indirecta ${ }^{43}$, artículo 226 injuria por vías de hecho ${ }^{44}$, artículo 227 injurias recíprocas ${ }^{45}$, artículo 229 violencia intrafamiliar ${ }^{46}$, artículo 230 maltrato mediante restricción a la libertad física ${ }^{47}$, artículo 233. Inasistencia alimentaría ${ }^{48}$, articulo 236. Malversación y dilapidación de bienes de familiares ${ }^{49}$, articulo 239 . Hurto simple ${ }^{50}$, artículos 239 y 241 hurto agravado ${ }^{51}$, artículo 240. Hurto calificado ${ }^{52}$, artículos 240 y 241 hurto calificado y agravado ${ }^{53}$, articulo 243. Alteración, desfiguración y suplantación de marcas de ganado ${ }^{54}$, articulo 246. Estafa ${ }^{55}$, articulo 248. Emisión y transferencia ilegal de cheque ${ }^{56}$, articulo 249. Abuso de confianza ${ }^{57}$, articulo 251. Abuso

Ibíd.

43 Ibíd.

44 Ibíd.

45 Ibíd.

46 Ibíd.

47 Ibíd.

48 Sólo si el sujeto pasivo es menor de edad.

49 Siempre y cuando el sujeto pasivo sea un menor de edad.

50 Siempre y cuando la cuantía de lo apropiado exceda de los 150 salarios mínimos mensuales legales vigentes.

51 Ibíd.

52 Siempre y cuando no haya violencia sobre las personas, ni se cometiere sobre medio motorizado, o sus partes esenciales, o sobre mercancía o combustible que se lleve en ellos. Así mismo, tampoco si se presenta la causal de agravación punitiva del numeral $1^{\circ}$ del ARTÍCULO 267 de la Ley 906 de 2004, pues elevaría el mínimo de la pena sobre el límite de los 5 años establecidos como límite para la mediación.

53 Ibíd. mínimos mensuales legales vigentes o si la cuantía es inferior si el sujeto pasivo es un menor de edad. En ambos casos, siempre y cuando no estén presentes ni la causal $2^{\mathrm{a}}$ o la causal $3^{\mathrm{a}}$ de agravación del ARTÍCULO 247 del Código Penal.

56 Siempre y cuando el sujeto pasivo sea un menor de edad.

57 Ibíd. de condiciones de inferioridad, articulo 252. Aprovechamiento de error ajeno o caso fortuito ${ }^{58}$, articulo 253. Alzamiento de bienes ${ }^{59}$, articulo 254. Sustracción de bien propio, articulo 255. Disposición de bien propio gravado con prenda ${ }^{60}$, articulo 259. Malversación y dilapidación de bienes $^{61}$, articulo 261. Usurpación de tierras ${ }^{62}$, articulo 262. Usurpación de aguas ${ }^{63}$, articulo 263. Invasión de tierras o edificaciones ${ }^{64}$, articulo 264. Perturbación de la posesión sobre inmueble ${ }^{65}$, articulo 265. Daño en bien ajeno ${ }^{66}$, articulo 270. Violación a los derechos morales de autor, artículo 271. Violación a los derechos patrimoniales de autor y derechos conexos, artículo 272. Violación a los mecanismos de protección de derecho de autor y derechos conexos, y otras defraudaciones.

De otra parte, y lo más interesante en el sistema acusatorio colombiano, la mediación se puede aplicar a todos los demás delitos investigables de oficio a un cuando la pena supere los cinco años de prisión siempre y cuando el bien jurídico protegido no sobrepase la órbita personal del perjudicado y víctima, imputado o acusado acepten expresa y voluntariamente someter su caso a una solución de justicia restaurativa. Expresa la norma que en los delitos con pena superior a cinco años la mediación será considerada para otorgar algunos beneficios durante el trámite de la actuación, o relacionados con la dosificación de la pena, o el purgamiento de la sanción.

58 Ibíd.

59 Ibíd

60 Ibíd.

61 Ibíd.

62 Ibíd.

63 Siempre y cuando sean aguas privadas y el sujeto pasivo sea menor de edad.

64 Siempre y cuando el sujeto pasivo sea un menor de edad.

65 Ibíd.

66 Ibíd. 


\section{EFECTOS DE LA MEDIACIÓN Y SUS CONSECUENCIAS EN EL PROCESO PENAL}

El artículo 526 de la Ley 906 de 2004 establece: "La decisión de víctima y victimario de acudir a la mediación tiene efectos vinculantes, en consecuencia, excluye el ejercicio de la acción civil derivada del delito y el incidente de reparación integral. El mediador expedirá un informe de sus resultados y lo remitirá al fiscal o al juez, según el caso, para que lo valore y determine sus efectos en la actuación. Los resultados de la mediación serán valorados para el ejercicio de la acción penal; la selección de la coerción personal, y la individualización de la pena al momento de dictarse sentencia". Se precisa que lo que produce efectos no es el hecho de acudir la mediación, un principio de la justicia restaurativa es que las partes se pueden retirar del mecanismo cuando lo considera que no se garantiza sus derechos. Realmente lo que produce efectos o consecuencias procesales es el acuerdo que se lleguen las partes.

Sin embargo, el artículo citado debe ser leído en conjunto con el inciso $2^{\circ}$ del artículo 524 de la misma ley, artículo que dice: "En los delitos con pena superior a cinco (5) años la mediación será considerada para otorgar algunos beneficios durante el trámite de la actuación, o relacionados con la dosificación de la pena, o el purgamiento de la sanción".

Conociendo las normas principales que regulan el asunto de nuestro interés deberemos pasar a ocuparnos de los efectos de la mediación. En el acápite de los delitos para los que procede la mediación explicamos que esta procede para todos los delitos, siempre y cuando el bien jurídico protegido no sobrepase la órbita personal del perjudicado, y víctima, imputado o acusado acepten expresa y voluntariamente someter su caso a una solución de justicia restaurativa, lo que pasa es que los efectos de una mediación difieren según el tipo de delito. A continuación explicaremos las diferencias en los efectos de la mediación de acuerdo a la clase de delitos de que se trate:

a) Delitos querellables, siempre y cuando el bien jurídico protegido no sobrepase la órbita personal del perjudicado, y la víctima y el imputado o acusado acepten expresa y voluntariamente someter su caso a una solución de justicia restaurativa: habíamos mencionado que en los delitosquerellables la conciliación es el mecanismo de justicia restaurativa al que las partes deben acudir, en virtud del artículo 522 de la Ley 906 de 2004, que instituye a la conciliación como requisito de procedibilidad para el ejercicio de la acción penal. Sin embargo, el inciso segundo del artículo 522 ibídem abre campo a la posibilidad de la práctica de la mediación en delitos querellables, pues determina que si la conciliación fracasa, bien sea por falta de acuerdo o por falta de asistencia del querellado, el fiscal del caso deberá proseguir con el ejercicio de la acción penal, sin perjuicio "de que las partes acudan al mecanismo de la mediación". Entonces, en este caso, al igual que lo que ocurre en los delitos perseguibles de oficio ${ }^{67}$ cuyo mínimo de pena no exceda de cinco (5) años de prisión, siempre y cuando el bien jurídico protegido no sobrepase la órbita personal del perjudicado, y víctima, imputado o acusado acepten expresa y voluntariamente someter su caso a una solución de justicia restaurativa, las consecuencias de la mediación pueden ser:

- No ejercicio de la acción penal: el inciso $3^{\circ}$ del artículo 526 de la Ley 906 de 2004 ordena que "Los resultados de la mediación serán valorados para el ejercicio de la acción penal". Así mismo, el numeral $8^{\circ}$ del artículo 324 ibídem señala que el principio de oportunidad se aplicará "8. Cuando proceda la suspensión del procedimiento a prueba en el marco de la justicia restaurativa y como consecuencia de este se cumpla con las condiciones impuestas". Entonces, reiteramos, el primer mecanismo de justicia restaurativa en los delitos querellables es la conciliación preprocesal del artículo 522 ibídem. Si la conciliación fracasa, las partes, sin

67 Esta es la interpretación que debe darse al inciso $2^{\circ} \mathrm{del}$ ARTÍ́CULO 522 de la Ley 906 de 2004. 
embargo, pueden acudir a la mediación. Adicionalmente, si se quiere que la mediación tenga efectos en relación con la aplicación del principio de oportunidad, tendrá que proponerse su celebración antes de que venza el término del artículo 175 ibídem. Vencido este término, la mediación que se celebre hasta antes del comienzo del juicio público ${ }^{68}$ no tendrá efectos sino con las otras consecuencias que estudiaremos a continuación.

- Selección de la coerción personal. Puede presentar en el momento de aplicar una medida de aseguramiento, como es la privación de la libertar en el trámite del proceso. Sustituirla por una medida menos restrictiva como podría ser la prisión domiciliaria o la presentación del procesado en libertad cada cierto tiempo como una medida de control social. La selección de la coerción persona tendría lugar también en el momento de dictar sentencia condenatoriay conceder el procesado un subrogado penal, puede ser la prisión en cárcel por la prisión domiciliaria para cumplir la pena siempre que no coloque en peligro a la comunidad y menos a la víctima. Siempre que el condenado repare los daños ocasionados con el delito, salvo cuando se demuestre que está en incapacidad material de hacerlo.

- Consideración de los resultados de la mediación para la individualización de la pena al momento de dictarse sentencia: este aspecto es de gran claridad. Debe destacarse esque la reparación del daño ocasionado con la conducta punible ya había sido establecido como circunstancia de menor punibilidad en el artículo 55, numeral 6º del Código Penal, que dice: "Reparar voluntariamente el daño ocasionado aunque no sea en forma total. Así mismo, si se ha procedido a indemnizar a las personas afectadas con el hecho punible". Empero, en este momento debemos recordar que el resultado de una

68 Inciso $1^{\circ}$ del ARTÍCULO 524 de la Ley 906 de 2004. mediación no siempre irá circunscrito a una reparación entendida en sentido económico. Así, según lo dispuesto por el inciso $2^{\circ} \mathrm{del}$ artículo 523 de la Ley 906 de 2004, el resultado de una mediación puede referirse "a la reparación, restitución o resarcimiento de los perjuicios causados; realización o abstención de determinada conducta; prestación de servicios a la comunidad; o pedimento de disculpas o perdón". Por lo tanto, el artículo 523 ibídem no es igual a la circunstancia de menor punibilidad del artículo 55, numeral 6 , del Código Penal, sino que aumenta su radio de acción, en la medida que incluye a todos los resultados exitosos de la mediación como circunstancia que debe ser tenida en cuenta al momento de dosificar la pena. Finalmente, debemos destacar que estimamos que el resultado exitoso de una mediación que tenga lugar antes de que venza el término del artículo 175 de la Ley 906 de 2004 debe ${ }^{69}$ tener como consecuencia el no ejercicio de la acción penal. En esa misma línea, una mediación que tenga lugar después de presentado el escrito de acusación y antes de que inicie el juicio oral ${ }^{70}$ deberá tenerse en cuenta para efectos de la individualización de la pena.

b) Delitos perseguibles de oficio cuyo mínimo de pena no exceda de cinco (5) años de prisión, siempre y cuando el bien jurídico protegido no sobrepase la órbita personal del perjudicado, y la víctima y el imputado o acusado acepten expresa y voluntariamente someter su caso a una solución de justicia restaurativa: en este caso las consecuencias son iguales a las que mencionamos al referirnos a los delitos

69 Se considera que se debe aplicar el principio de oportunidad, pues si es de la esencia de la mediación en materia penal resolver de manera satisfactoria y expedita para las partes (víctima y ofensor) los conflictos sociales generados por la comisión del delito nada sería más contrario a este espíritu que continuar un proceso penal en el que a la víctima le haya sido reparado el daño causado (o cualquier otra de las manifestaciones de la justicia restaurativa que sea satisfactoria para la víctima).

70 ARTíCULO 524 de la Ley 906 de 2004. 
querellables, es decir, no ejercicio de la acción penal y consideración de los resultados de la mediación para la individualización de la pena al momento de dictarse sentencia.

c) Delitos perseguibles de oficio cuyo mínimo de pena sí exceda de cinco (5) años de prisión, siempre y cuando el bien jurídico protegido no sobrepase la órbita personal del perjudicado, y la víctima y el imputado o acusado acepten expresa y voluntariamente someter su caso a una solución de justicia restaurativa: en este tipo de delitos la mediación se tiene en cuenta "para otorgar algunos beneficios durante el trámite de la actuación, o relacionados con la dosificación de la pena, o el purgamiento de la sanción"71. A continuación procederemos a estudiar tales efectos.

Otorgamiento de beneficios durante el trámite de la actuación: en este caso podemos considerar como beneficio, por ejemplo, la sustitución de la detención preventiva en establecimiento carcelario por la del lugar de residencia.

Dosificación de la pena: las consideraciones que hicimos sobre este aspecto al tratar los delitos querellables son similares para este caso.

Purgamiento de la sanción: en este caso, por ejemplo, se trata de otorgar al condenado beneficios tales como concederle la prisión domiciliaria como sustitutiva de la prisión, de que trata el artículo 38 del Código Penal. Así mismo, también puede considerarse la mediación para efectos de la concesión de la libertad condicional de que trata el artículo 64 ibídem, punto que va en clara concordancia con la reforma hecha a este artículo previamente por la Ley 890 de 2004 que incluyó a la reparación a la víctima como uno de los requisitos que deben ser tenidos en cuenta para la concesión de este beneficio.

71 Inciso $2^{\circ}$ del ARTíCULO 524 de la Ley 906 de 2004.
Por último, estudiados los efectos de la mediación en el ámbito penal, debemos estudiar sus efectos en el aspecto civil:

Señalábamos que el artículo 526 de la Ley 906 de 2004 establece que "La decisión de víctima y victimario de acudir a la mediación tiene efectos vinculantes, en consecuencia, excluye el ejercicio de la acción civil derivada del delito y el incidente de reparación integral". Así, una mediación que termine de manera exitosa tendrá como resultado que la víctima no podrá acudir ante el juez penal en el incidente de reparación integral que tiene lugar luego de emitido el fallo ${ }^{72}$; tampoco podrá iniciar una acción de responsabilidad civil extracontractual ante el juez civil. En conclusión, el acuerdo logrado en la mediación incluye, obviamente, un arreglo en cuanto a la determinación del monto de la indemnización por los perjuicios ocasionados por la comisión de la conducta punible, lo que excluye el ejercicio de cualquier acción jurídica tendiente a buscar tal indemnización, pues esta ya ha tenido lugar.

\section{CONCLUSIONES}

Con la mediación penal, como mecanismo alternativo al proceso penal se puede ahorrar un enjuiciamiento formal, particularmente cuando la aplicación satisfactoria de medidas de justicia restitutiva apoya la prognosis de que el delincuente no cometerá más delitos. Los jueces y fiscales investigadores pueden alentar al delincuente y a la víctima a avanzar gradualmente hacia la reconciliación, teniendo en cuenta que el restablecimiento de la paz entre la víctima, el delincuente y la comunidad puede requerir un proceso a mediano o hasta a largo plazo. El concepto de la justicia restitutiva puede ampliar la función de un testigo que, al mismo tiempo,

72 ARTíCULO 102 de la Ley 906 de 2004. 
es víctima de un delito. En la preparación para la audiencia, el juez o el fiscal investigador deben asegurar a la víctima el acceso adecuado al tribunal. El juez y el fiscal investigadores también deben proporcionar a la víctima toda la información necesaria sobre sus derechos, así como sobre los programas existentes de asistencia e indemnización a las víctimas y otros servicios, como el tratamiento médico y la protección en lugares seguros, por ejemplo, en hogares para mujeres.

La aplicación de programas de mediación penal ayudará a reducir la carga de causas y asegurará que el sistema de justicia penal se ocupe sólo de los casos en que se requiere una intervención formal y firme del sistema.

El encarcelamiento suele crear una situación en que los delincuentes sin recursos y sin posibilidad de trabajar con remuneración, por lo tanto, no pueden indemnizar a las víctimas. Hay varias medidas que se pueden aplicar para que los delincuentes sentenciados puedan indemnizar a las víctimas, incluida la libertado bajo palabra y la excarcelación para trabajar, así como el servicio comunitario, teniendo en cuenta que las medidas distintas de la privación de la libertad también pueden ayudar a aliviar el hacinamiento en las cárceles.

Otra alternativa a la prision, como consecuencia o resultado de una mediación penal es la vigilancia electrónica. Si bien la instalación de esos sistemas puede ser costosa, a la larga reduce los costos del mantenimiento del encarcelamiento y ayuda a mantener la vida familiar del delincuente y sus vínculos con la comunidad y con oportunidades de empleo remunerado. Ahora bien, el uso de la vigilancia electrónica debe ser cuidadosamente considerado para detectar posibles violaciones de los derechos humanos, a fin de asegurar que solo estén sometidos a vigilancia los delincuentes que de otra forma estarían encarcelados, evitando así la denominada ampliación de la celda.

Es necesario para lograr los fines del Estado: de una pronta y cumplida justicia, de reaccionar frente al delito, de lograr la reparación de las víctima y de sobretodo de mantener la pacificación en la convivencia en la comunidad, acudir a dispositivo alternos al proceso penal. La mediación penal como mecanismo de justicia restaurativa puede logar la solución en parte a la congestión judicial en materia criminal, porque se ocupa de tratar los delitos más graves los investigables de oficio.

La dificulta que se encuentra para la aplicación de la mediación penal en el país, es su desconocimiento por parte de los operadores de la justicia. Si bien, esta figura esta en el código de procedimiento penal, se requiere su reglamentación para ser más operable. El fiscalía, encargada de reglamentarla de conformidad con la ley, apenas tiene una manual de instrucciones donde terminar por confundir la mediación con la conciliación y sin darle los alcances que tiene la mediación penal, resultando inoperable esta novedosa figura penal. No se conocer quienes son los particulares que pueden ser mediadores y menos los servidores públicos que pueden fungir como tales. La medición penal es una actividad exigente, requiere de todo un equipo interdisciplinario empezando por el abogado penalista, con gran experiencia, psicólogos, trabajadores sociales, para hacer operable la justicia restaurativa. Además que debe tener el apoyo del ente acusador, de los jueces y con la voluntad de Estado aportando los recursos económicos para fomentar y desarrollar la mediación penal como mecanismo de justicia restaurativa para que sea una realidad en Colombia.

Teniendo en cuenta el nuevo modelo imperante con orientación punitivo garantista, se entiende al joven o adolescente como un sujeto, no solo titular de derechos legales y sociales sino como un integrante mas de la sociedad responsable por sus actuaciones frente a la ley penal.

\section{BIBLIOGRAFÍA}

ALONSO RIMO, Alberto. Víctima y sistema penal: Las infracciones no perseguibles de oficio y el perdón del ofendido. Editorial Tirant lo Banch. Valencia, 2002. 
ALZATE, N. (1989). El Fenómeno de las Desapariciones Forzada. Tesis de Grado Universidad Nacional de Colombia, Facultad de Derecho. Bogotá, Colombia.

AMNISTÍA INTERNACIONAL (s.f.) Manual Para La Acción, Desapariciones Forzadas y Homicidios Políticos: La Crisis de Los Derechos Humanos. EDAI.

AMSTRONG, S. (s.f.). Pinochet; Is a Terrorist Hiding in Chile's Senate?. [Citado 7 Ago] Disponible en Internet: http://www.izquierdaunida.es/Derechos

ASFADDES. (2003). Veinte Años de Historia y Lucha. Rodríguez Quito Editores. Bogotá, Colombia.

BERISTAIN - IPIÑA, Antonio. "Criminología, Victimología y Cárceles". Tomo I. Pontificia Universidad Javeriana. Facultad de Ciencias Jurídicas. Colección Profesores 22, Bogotá, 1996.

BERISTAIN, A. ¿La Sociedad/Judicatura Atiende a "Sus" Víctimas/Testigos? En: 50vo Curso Internacional de Criminología: "Justicia y Atención a Víctimas del Delito". México. 1995.

BERISTAIN, C. y RIERA, F. Afirmación y Resistencia, La Comunidad Como Apoyo. Virus Editorial. Barcelona. 1993.

BOTERO, R. La Desaparición Forzada. Revista Su Defensor, Año 3, No. 25, 1995, Ago. p. 12-15.

BRIGHT, Ch. Mediación entre Víctima y delincuente. 1997. Disponible en Internet: http:// www. restorativejustice. org.

BROOKERS, D. Evaluating Restorative Justice Programs. United Nations Crime Congreso. Vienna, Austria. 2000.

BUSTOS RAMÍREZ, Juan y Larrauri Elena. Victimología: Presente y futuro. Temis. Bogotá, 1993.

CONFRATERNIDAD CARCELARIA
INTERNACIONAL (s.f.). Justicia Restaurativa. [Citado 25 Ago. 2003] Disponible en Internet: http://www.restorativejustice.org.

CONSEJODESEGURIDADDELASNACIONES UNIDAS. E/CN.154/2002/5 Add.1 Informe del Grupo de Expertos sobre Justicia Restaurativa a la Comisión de Prevención del Delito y Justicia Penal.

CONSEJO MUNDIAL DE LAS IGLESIAS (s.f.). Justicia Restauradora. [Citado 1 Sep. 2003] Disponible en Internet http://www.wcc-coe.org/ wcc/what/international/restorative-s.html

CONWAY, P. (s.f.). Truth and Reconciliation: The Road Not Taken in Namibia. [Citado 25 Ago. 2003] Disponible en Internet http://www. trinstitute.org/ojpcr/5 1conway.htm

GARZÓN, B. (s.t.) En: Revista Cromos. Bogotá, Colombia. Ago. 11. 2003

GAVIRIA, V. Algunos Aspectos Civiles Dentro del Proceso Penal. Ed. Universidad Externado de Colombia. Bogotá Colombia. 1999.

GIMÉNEZ-SALINAS, Esther, y otros: Mediación Penal, Generalitat de Catalunya, Departamento de Justicia, 1999; MAIER, F.: "La Victima en el sistema penal", en Jueces para la Democrácia No12,1991.

GONZALEZ CAPITAL, C. (1999). Manual de Mediación . Barcelona: Atalier.

GONZALEZNAVARRO, A. L. (2007). La Víctima en el Sistema Penal . Bogotá: Leyer.

GONZALEZNAVARRO, Antonio Luis. La Justicia Restaurativa y El Incidente de Reparación En el Proceso Penal Acusatorio. Leyer. Bogotá D.C., 2009.

GORDILLOSANTANA, L. F. (2003). La Mediación Penal - Caminando hacia un Nuevo Concepto de Justicia. Madrid : Elementos Esenciales de la Mediación.

MARTINEZ ARRIETA, A. (2002). La Mediación 
Penal y su incorporación al Proceso Penal Español. I Jornadas sobre Mediación Penal y Drogodependiencias. Madrid: Asociación Apoyo.

MARQUEZCARDENAS, Alvaro Enrique. La víctima en el sistema acusatorio y los mecanismos de justicia restaurativa. Editorial Ibañez, Bogotá, 2011.

MARTÍNEZ RAVE, G. (2002). La Conciliación en el Proceso Penal Colombiano (3a. ed.). Bogotá: Temis S.A.

MARTÍNEZ, A. Tortura, salud y desarrollo humano. Seminario Nacional. Enfoque y Metodologías de Atención Psicosocial en el marco del conflicto sociopolítico colombiano. Universidad Javeriana. Nov. 27 - 282003 Bogotá, Colombia.

MCEVOY, K. Justicia Restaurativa y el conflicto de Irlanda del Norte. Conferencia Universidad Nacional. Nov. 20 2003. Bogotá, Colombia.

SEGOVIA BERNABE, J. (2002). Algunos criterios para el disernimiento: La experiencia de la Asociación Apoyo en los Juzgados de Madrid. I Jornadas sobre Mediación Penal y Drogodependiencia. Madrid: Asociación Apoyo.
SEGOVIA BERNABE, J. (2003). La Seguridad Ciudadana y Las Víctimas. Pistas éticas para humanizar el Proceso Penal . Gobernanza y Seguridad Sostenible . Barcelona: IIG.

SINTURA VARELA, F., \& LOMBANA VILLALBA, J. (2005). Sistema Penal Acusatorio. Bogotá: Universidad del Rosario - Facultad de Jurisprudencia.

SIX, J. F. (1997). Dinámica de la Mediación . Barcelona : Paidós.

SUARES, M. (1996). Mediación, Conducción de Disputas. Comunicación y Técnicas. Buenos Aires: Paidos.

SUEIRO, Carlos Christian. La naturaleza jurídica de la reparación del daño desde una perspectiva penológica, criminológica, dogmática y procesalista político criminal, Fabián Di Placido Editor, 2006).

TAMARIT SUMALLA, J. M. (1994). La Reparación a la Víctima en el Derecho Penal. Barcelona: Fundación Jaime Callís. 